\title{
THE DETERMINANTS OF FOREIGN DIRECT INVESTMENT IN CHINA: A SPATIAL PANEL ANALYSIS
}

\author{
CHEN-CHEN YONG \\ SIEW-YONG YEW \\ XIN HUANG \\ Faculty of Economics and Administration \\ University of Malaya \\ MUI-YIN CHIN \\ Economics \& Corporate Administration Department \\ Tunku Abdul Rahman University College
}

\begin{abstract}
China is currently the major foreign direct investment (FDI) destination arising from her open door policies since 1978. FDI has become a large impetus to China's economic growth. However, the geographical distribution of FDI in China is severely biased with $83 \%$ concentrated in the eastern region. This is a result of not only differences in locational advantages but also the result of the initiating policies and temporal differences of FDI inflows among the regions. This study aims to examine the determinants of FDI and examine empirically the possible coherent policies for the three regions of China (Eastern, Central and Western) using the spatial panel analysis for the data within the period of 1994 to 2008. The empirical results show that the determinants of FDI vary among the three regions, depending on the motives of the investor and the results of policy bias. The entrepreneurial nature of competition of FDI among the provinces revealed by the spatial FDI factor is a conclusion that cannot be ignored. A more coherent policy on FDI inflows into China is an urgent necessity, though the policies for each region must be, of necessity, different for each of the three regions.
\end{abstract}

Keywords: Foreign Direct Investment, China, Spatial panel model, spatial variables JEL: F14, C33

\section{Introduction}

Since the establishment of economic reforms in 1978, China's economy has gradually opened up to the rest of the world with increasing 
foreign direct investment (FDI) inflows and international trade. The inflows of FDI have surged drastically since the 1990s after Deng Xiaopeng's South Tour in 1993 (Cheung \& Lin, 2004). Arising from the successful policy, China has emerged as the largest recipient of FDI among developing nations in 1990s. Furthermore, the inflows of FDI to China have been further uplifted after China is ascension to the World Trade Organization (WTO) in 2001. Forbes (2005) states that the inflow of FDI to China has increased from USD 45.5 billion in 1998 to more than USD 50 billion in 2003, surpassing that of the United States, to become the world's largest recipient of FDI. Ten years later, the amount of FDI inflow into China increased to US\$124 billion (GMID, 2015). The locational advantage has widened the unequal distribution of FDI among the Eastern, Central and Western regions. As FDI is instrumental in China's economy, this study aims to examine the determinants of FDI inflow into the respective three regions of China (Eastern, Central and Western) using the spatial panel model. In order to formulate a coherent policy to attract FDI to China, the findings of the study could provide a better understanding on how the spatial FDI factors have contributed to the success of FDI.

\section{Policy Developments for FDI}

The commencement of FDI inflow started with the promulgation of the Equity Joint Venture Law in July 1979, providing the legal framework for foreign investors to participate as joint venture partners with Chinese partners (Fu, 2000). This was followed by the establishment of four special economic zones (SEZs) in Guangdong and Fujian provinces (Fu, 2000), with three core objectives to develop the coastal areas of China through experimental controlled enclaves, to attract foreign investment and to serve as China's window to the outside world (McKenney, 1993). From the early days, the policies on FDI have been strongly biased towards the coastal regions, particularly, the south-east coastal region. From the four SEZs, 14 coastal port cities were opened to foreign trade in 1984 which soon established their own Economic and Technological Development Zones to encourage foreign trade and investment.

China promulgated the Law on Enterprises Operated Exclusively with Foreign Capital and Provision on Encouraging Foreign Investment in 1986 to lift restrictions on foreign ownership, implemented new incentives and removed uncertainties for foreign investors. From 1988 to 1990, the coastal open economic area was extended to North 
China Hainan Island was declared a province, and the fifth SEZ and Shanghai were approved to develop the Pudong New Area as an international economic, financial and transport centre. Such policies coupled with Deng XiaoPing's southern tour in 1992 and encouragement for China to accelerate economic reform and open up further, opened the flood gates to bring in more foreign investments. To address structural differences, reforms were introduced to move investments westwards and inland to reduce the disparity in income between the coastal and inland areas. China entered a high growth phase in FDI inflows. This was followed by the ascension of China to the World Trade Organization (WTO). With China adopting policies to boost transparency, improving intellectual property protection, reducing tariffs and taxes and privatizing state-owned enterprises, there is an increased confidence in China by foreign enterprises. The subsequent influx of FDI became more myriad by sectors and source countries.

FDI is a strong impetus to China's economic development which promotes China's rapid and sustainable growth. As pointed out by Zhao and Zhang (2010), FDI has positive spillover effect in enhancing industrial productivity level in China. This is attributable to the benefits that the domestic firms received from the inflow of FDI. The domestic firms can derive technological know-how and demonstration effects on innovation activities via the inflow of FDI (Cheung \& Lin, 2004). Furthermore, the inflow of FDI is crucial for China as investment is the main component of China's GDP which accounted for more than $40 \%$ (Boumphrey, 2014).

From the chronological description above and the initiating policies and geographical starting points of the promotion of FDI inflow into China, one can expect that the focus on the coastal areas will create imbalances in development levels both from the volume and quality. The type of FDI is expected to be different as well. Economically and administratively, China has been divided into three regions, namely Eastern, Central and Western. The Eastern region includes the provinces of Beijing, Tianjin, Hebei, Liaoning, Shanghai, Jiangsu, Zhejiang, Fujian, Shandong, Guangdong, and Hainan, which comprise the coastal regions and the SEZs first promoted for foreign trade and investment. The Central region includes the provinces of Shanxi, Jilin, Heilongjiang, Anhui, Jiangxi, Henan, Hubei and Hunan, just adjacent to the Eastern region. Meanwhile, the Western region includes the provinces of Inner Mongolia, Guangxi, Hongqing, Sichuan, Guizhou, Yunnna, Tibet, Shaanxi, Gansu, Qinghai, Ningxia and Xinjiang, which 
is adjacent to the Central region and separated from the coastal region by the Central region. Table 1 and Table 2 show the distribution and annual growth rate of GDP and FDI respectively in the three regions of China.

Table 1

Distribution and Annual Growth Rate of GDP in the Three Regions of China

\begin{tabular}{ccccccc}
\hline Year & $\begin{array}{c}\text { E-GDP(in } \\
\text { USD } \\
\text { million) }\end{array}$ & $\begin{array}{c}\text { E-GDP } \\
\text { growth } \\
\text { rate (\%) }\end{array}$ & $\begin{array}{c}\text { C-GDP } \\
\text { (in USD } \\
\text { million) }\end{array}$ & $\begin{array}{c}\text { C-GDP } \\
\text { growth } \\
\text { rate }(\%)\end{array}$ & $\begin{array}{c}\text { W-GDP (in } \\
\text { USD million) }\end{array}$ & $\begin{array}{c}\text { W- GDP } \\
\text { growth rate } \\
(\%)\end{array}$ \\
\hline 1994 & 293272.9 & - & 135054.4 & - & 89655.73 & - \\
1995 & 331007.1 & 12.9 & 154191 & 14.2 & 117709.3 & 31.3 \\
1996 & 359036.2 & 8.5 & 172631.7 & 12 & 129350 & 9.9 \\
1997 & 393705 & 9.7 & 190085.7 & 10.1 & 127577 & -1.4 \\
1998 & 431595.3 & 9.6 & 204736.1 & 7.7 & 135948.6 & 6.6 \\
1999 & 469969.1 & 8.9 & 215097.6 & 5.1 & 144449.6 & 6.3 \\
2001 & 575329.6 & 9.5 & 254191.4 & 8.4 & 169710.3 & 8.8 \\
2002 & 642909.8 & 11.8 & 276701.8 & 8.9 & 189003.5 & 11.4 \\
2003 & 740093.8 & 15.1 & 310858.6 & 12.3 & 212554.7 & 12.5 \\
2004 & 893921.9 & 20.8 & 354793.2 & 14.1 & 255011.6 & 20 \\
2005 & 1966248 & 19.3 & 419655.4 & 18.3 & 301744.8 & 18.3 \\
2006 & 1267669 & 18.9 & 492590.7 & 17.4 & 361333.7 & 19.8 \\
2007 & 1533904 & 21 & 604572.9 & 22.7 & 446190.6 & 23.5 \\
2008 & 1799395 & 17.3 & 730391.4 & 20.8 & 556760.4 & 24.8 \\
\hline
\end{tabular}

Source: China's Statistical Yearbook (various issues)

Note: E-, C- and W-indicate Eastern, Central and Western regions respectively

In line with the implementation of the economic development strategies such as the Great Western Regional Development, revitalization the traditional-based industries in the Northeast region and the rise of Central China, the three regions of China experienced rapid economic growth (see Table 1). However, GDP distribution was different among the three regions. The share of GDP of the Eastern region remains the largest (58\%), followed by Central $(24 \%)$ and Western (18\%). Similarly, Table 2 reports that $83 \%$ of the FDI inflow is concentrated in the Eastern region for 1994-2008. Meanwhile, the Central and Western regions captured only $12 \%$ and 5\% of total FDI respectively, revealing a clear geographical bias. 
IJMS 23 (1), 13-31 (2016)

Table 2

Distribution and Annual Growth Rate of FDI in the Three Regions of China

\begin{tabular}{ccccccc}
\hline Year & $\begin{array}{c}\text { E-FDI(in } \\
\text { USD } \\
\text { million) }\end{array}$ & $\begin{array}{c}\text { E-FDI } \\
\text { growth } \\
\text { rate (\%) }\end{array}$ & $\begin{array}{c}\text { C-FDI } \\
\text { (in USD } \\
\text { million) }\end{array}$ & $\begin{array}{c}\text { C-FDI } \\
\text { growth } \\
\text { rate (\%) }\end{array}$ & $\begin{array}{c}\text { W-FDI(in } \\
\text { USD } \\
\text { million) }\end{array}$ & $\begin{array}{c}\text { W-FDI } \\
\text { growth } \\
\text { rate (\%) }\end{array}$ \\
\hline 1994 & 28383.72 & - & 2572.62 & - & 2311.31 & - \\
1995 & 31968.76 & 12.6 & 3371.55 & 31.1 & 2254.44 & -2.5 \\
1996 & 36206.45 & 13.3 & 3914.06 & 16.1 & 1977.98 & -12.3 \\
1997 & 39050.71 & 7.9 & 4779.23 & 21.1 & 2544.45 & 28.6 \\
1998 & 38603.99 & -1.1 & 4329.4 & -9.4 & 2401.15 & -5.6 \\
1999 & 34414.62 & -19.9 & 3682.85 & -14.9 & 1837.35 & -23.5 \\
2000 & 34886.49 & 1.4 & 3594.34 & -2.4 & 1905.15 & 3.7 \\
2001 & 40343.61 & 15.6 & 4101.2 & 14.1 & 1922.19 & 0.9 \\
2002 & 43457.34 & 12.7 & 5008.65 & 22.1 & 2108.69 & 9.7 \\
2003 & 45386.22 & -0.2 & 5831.46 & 16.4 & 1892.38 & -10.3 \\
2004 & 64717.01 & 42.6 & 8418.1 & 44.4 & 3127.99 & 65.3 \\
2005 & 70974.29 & 9.7 & 10982.3 & 30.5 & 4274.89 & 36.7 \\
2006 & 85853.15 & 21 & 14024.4 & 27.7 & 6180.73 & 44.6 \\
2007 & 101896.7 & 18.7 & 19516.5 & 39.2 & 6977.39 & 12.9 \\
2008 & 114472.5 & 12.3 & 23049.1 & 18.1 & 10390.16 & 48.9 \\
\hline
\end{tabular}

Source: Same as Table 1

Despite the similar distribution pattern of both GDP and FDI, it is also noticeable that the high FDI growth rate has led to a surge of GDP growth rate in all the three regions during 2001-2008 (see Table 1 and Table 2).

From the information above, FDI plays an influential role in the economic development of the three regions. In particular, from the parallel movements of FDI and GDP across the three regions, we can speculate that FDI does increase economic interaction among the provinces and from the spill-over effects as found by Coughlin and Segev (2000). Although FDI is instrumental in determining China's economic growth, it is observed that the annual growth rate of FDI inflow for the three regions is relatively volatile. The volatility is a point of concern given its unpredictable impacts that cause planned objectives to become distorted. Among all, the Western region has the greatest fluctuations in the annual growth rate of FDI (see Table 2).

The real impact of spill-overs and FDI inflow issues among the regions will be examined in this study. We will examine the determinants of FDI inflow into the three identified regions of China, 
respectively using the spatial panel model to provide insights on the extent of provincial competition and possible joint development in attracting FDI. In addition, the identified relationship between FDI and its determinants would serve as the yardstick to benchmark the backward linkages among the provinces in attracting FDI.

Section 2 reviews previous literature on the determinants of FDI in China. Section 3 describes and explains the methodology used in this study. Section 4 reports and discusses the empirical findings. Section 5 concludes.

\section{Literature Review on the Determinants of FDI in China}

Recent literature have categorized the determinants of FDI into micro- and macro- determinants. The main micro-determinants of FDI include the firm's size (Liu, 2010; Hale \& Long, 2011; Lin, 2010; Buckley et al., 2006, Jiang \& Wang, 2011), the firm's age (Hale \& Long, 2011; Girma et al., 2008; Jiang, Yang \& Wang, 2011), the firm's globalization strategy (Girma et al., 2008; Jiang and Wang, 2011), the product innovation-R\&D expenditure (Lin, 2010), the borrowing cost (Liu, 2010; Zheng, 2009; Pan, 2003), the investment incentives (Liu, 2010), the efficiency-seeking motive, the resource-seeking motive and the market-seeking motive (Liu, 2010; Jiang et al., 2011).

Challenges of the micro-level analysis have led to the preference of the macro-level analysis of FDI. Among the studies that analysed the macro-determinants of FDI into China are Boermans et al. (2009), Liu (2010), Kang \& Wang (2011), Lv et al. (2010) \& Huang and Wei (2010). Based on the literature above, the main macro-determinants of FDI comprise, among others, market size, potential market and growth of the host country which are variously proxied by using the GDP and the GDP per capita and labor costs.

Nevertheless, Wen (2007) put forward the argument that geographical advantage in export attracts FDI inflow into the Eastern region more than the other regions within China's border. In addition, Ho (2004), Sun (2002) and Zheng (2009) pointed out that market level is different among the regions in China. The cities and provinces in the Eastern region have larger market size and higher level of market demand in attracting market-seeking FDI which lead to uneven distribution of FDI in China. Boermans et al. (2009) empirically investigated the factors that drive the uneven regional distribution of FDI in China. The 
authors found that foreign investors preferred to invest in provinces with larger market size and lower labor cost. Meanwhile, Hong et al. (2008) found that the provinces with larger market size, adequate infrastructure, preferential policy for foreign investments, short geographical distance, short cultural distance, low labor cost and high labour quality will attract FDI inflow. Using the spatial dynamic panel data model, Hong et al. (2008) also added that FDI in the host province responds positively to FDI received by their neighbouring provinces but negatively to the GDP of the neighbouring provinces. In a nutshell, there is a wide range of determinants for FDI. However, the chosen determinants are largely based on the objectives of the research.

\section{Methodology}

This study adopts the spatial panel model to examine the inflow of FDI in China for the three regions attributable to the existence of the spill-over effects among the provinces in the respective regions. The selection of the independent variables for the econometric model are based on Dunning's Eclectic Paradigm theory (2001) or the OLI model on the motivation of FDI inflows based on ownership-specific $(\mathrm{O})$, locational (L) and internalization (I) advantages. Other past literature also classify FDI by motivation into strategic asset-seeking, market-seeking, efficiency-seeking and resource-seeking FDI. Marketseeking FDI is mainly motivated by the host countries' market size, the access to regional and global markets and the structure of the domestic market. On the other hand, resource-seeking FDI aims to gain comparative advantage. Hence, it is highly dependent on labour and resources, availability of cheap raw materials, infrastructure development and level of technology of the host countries. Meanwhile, efficiency-seeking FDI is driven by the advantage of low production cost in the host country to enhance the firm's competitiveness. The potential benefits derived from undertaking efficiency-seeking FDI are especially those of economies of scale and scope, which are derived from product and geographical concentration and from process specialization (Tahir \& Larimo, 2005, and Wadhwa \& Reddy, 2011). Owing to the different motives of the FDI, the impact of the independent variables on FDI inflow is expected to be varied. Most of the empirical findings show market-seeking is the dominant motive of FDI, followed by resource-seeking and efficiency-seeking (Wei et al., 2001; Zhang, 2001). 
FDI inflow (FDI) is adopted as the default dependent variable of the spatial panel model while the independent variables consist of the GDP which proxies for market size, wage rate (Wage) which proxies for labour cost and the spatial variables, namely spatial FDI (SFDI), spatial GDP (SGDP) and spatial wage rate (SW). These spatial variables are intended to capture the spill-over effects of both the dependent and independent variables. The empirical model is shown in an equation (1) as follows:

$$
\begin{aligned}
& \mathrm{FDI}_{\mathrm{it}}=\alpha+\beta_{1} \mathrm{GDP}_{\mathrm{it}}+\beta_{1} \mathrm{Wage}_{\mathrm{it}}+\beta_{3} \mathrm{SFDI}_{\mathrm{it}}+\beta_{4} \mathrm{SGDP}_{\mathrm{it}}+ \\
& \beta 5 \mathrm{SW}_{\mathrm{it}}+\varepsilon_{\mathrm{it}}
\end{aligned}
$$

where $i(i=1, \ldots, N)$ refers to a spatial unit, $t(t=1, \ldots, T)$ refers to a given time period, $\beta$ refers to fixed but unknown parameter and $\varepsilon_{\mathrm{it}}$ refers to independently and identically distributed error terms for all $\mathrm{i}$ and $t$ with zero mean and variance $\sigma^{2} . S$ is the spatial weight matrix following row standardised contiguity matrix shown as follows:

$$
S_{i \bar{i}}^{*}=\left(S_{\bar{i}} / \sum_{j} S_{i}\right)
$$

where $S_{i j}=1$ is for contiguous provinces and 0 otherwise. The data for $S_{i j}$ is defined as contiguous among provinces that share a land or water border. The empirical model mentioned above is subjected to spatial panel analysis. The three spatial models, namely spatial lag, spatial error and spatial Durbin model are formulated as equations below:

$$
\begin{aligned}
& F D I_{\text {it }}=\delta \sum_{j=1}^{N} S_{i j} F D I_{\text {it }}+\alpha+\beta X_{\text {it }}+U_{i}+\partial_{t}+\varepsilon_{\text {if }} \\
& F D I_{\mathrm{it}}=\alpha+\beta X_{\mathrm{it}}+U_{\mathrm{i}}+\partial_{\mathrm{i}}+\gamma_{\mathrm{it}}+\varepsilon_{\mathrm{it},} \gamma_{\mathrm{H}} \rho \sum_{\mathrm{j}=1}^{\mathrm{W}} S_{\mathrm{i} \mathrm{V}_{\mathrm{it}}}+\varepsilon_{\mathrm{il}} \\
& F D I_{\text {it }}=\delta \sum_{j=1}^{W} S_{i j} F D I_{\text {it }}+\alpha+\beta X_{\text {it }}+\sum_{j=1}^{W} \varphi S_{i j} X_{i j}+U_{i}+\partial_{i}+\varepsilon_{\mathrm{i}}
\end{aligned}
$$

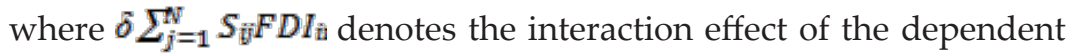
variable of one province with the dependent variables in the neighboring provinces, where $S_{i j}$ is the $\mathrm{i}$, $\mathrm{j}$-th element of a prespecified nonnegative $\mathrm{NxN}$ spatial weights matrix $S$, describing the arrangement of the spatial units in the sample. The response parameter of these endogenous interaction effects, ó, is assumed to be restricted to the interval $\left(1 / r_{\min }, 1\right)$, where $r_{\min }$ equals the most negative purely real characteristic root of $S$ after this matrix has been row-normalized (see LeSage \& Pace, 2009, pp.88-89 for mathematical details). $\alpha$ is the constant term parameter while $X_{i t}$ is a $1 \times k$ vector of exogenous variances, and $\beta$ is a matching $K x 1$ vector of fixed but unknown parameters. Besides, $U_{i}$ denotes spatial specific effect which 
control for all space-specific time-invariant variables whose omission could bias the estimates in a typical cross-sectional study. Meanwhile, $\alpha_{t}$ denotes the time-period specific effect which controls all the timespecific effects whose omission could bias the estimates in a typical time-series study (Baltagi, 2005). $\rho$ denotes the spatial autocorrelation coefficient and $\sum_{j=1}^{N} \varphi S_{i j} X_{i j \pi}$ denotes the interaction effect between one province and the independent variables of neighboring provinces.

The spatial Durbin model which was advocated after 2007 (Elhorst, 2010) extends the spatial lag model with spatially lag independent variables. This model is more general and flexible as it does not impose any prior restriction on the potential spillover effect (Elhorst, 2010). As such, this study will adopt the spatial Durbin model to treat the data. However, to enhance the reliability and the robustness of the estimated results, both the Likelihood Ratio (LR) test and the Wald test are employed to examine whether the spatial Durbin model can be simplified to spatial lag and spatial error model. If both tests are significant, it enhances that the Spatial Durbin model is the best model to estimate the results.

Nevertheless, the fixed effect instead of the random effect model will be employed in this study. As pointed out by Elhorst (2003), fixed effects are more convincing than the random effects owing to the restrictive nature of the random effects.

\section{Definition and Source of Data}

The annual data by provinces of China for this study were obtained from various issues of China's Statistical Yearbook for the period of 1994 to 2008. Tibet is excluded from this study due to missing data. In addition, this study has not included Taiwan, Hong Kong and Macau owing to their unique system and municipalities.

\section{Empirical Results}

The non-spatial model are divided into four types, namely pooled OLS, panel model with spatial fixed effects, panel model with time period fixed effects, and panel model with both spatial and time period fixed effects. The econometric results show that the panel model with the spatial fixed effect and the time-period fixed effect is preferred to the other forms of models in describing the data for all regions of China. The estimated results are presented in Table 3. 
IJMS 23 (1), 13-31 (2016)

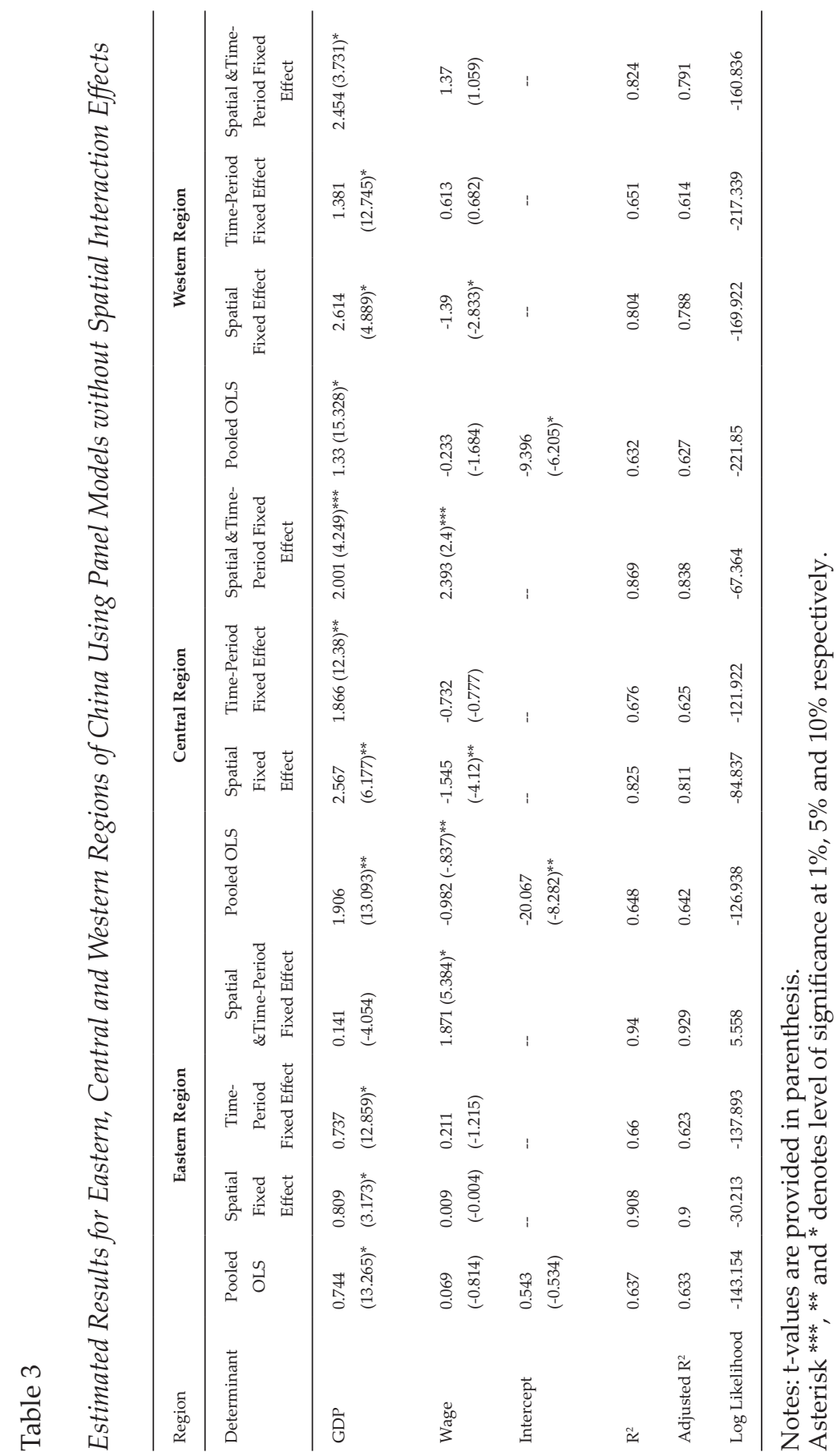


From Table 3, it is noticeable that the adjusted $\mathrm{R}^{2}$ values and the Log Likelihood values of 0.929 and 5.558 for the Eastern region, 0.838 and -67.364 for the Central region as well as 0.791 and -160.836 for the Western region of the panel model with the spatial and time-period fixed effects are the highest among all the models for the three regions respectively. Hence, the spatial Durbin model specification with the spatial and time-period specific effects would be adopted to examine the determinants of FDI. The estimated results are presented in Table 4 .

Table 4

Estimated Results for the Determinants of FDI

\begin{tabular}{lccc}
\hline Determinants & Eastern Region & Central Region & Western Region \\
\hline GDP & -0.027 & $3.939(3.825)^{* *}$ & $3.834(3.025)^{* *}$ \\
& $(-0.075)$ & & \\
Wage & 1.341 & $-0.865(-0.773)$ & $-2.425(-1.77)^{*}$ \\
& $(2.674)^{* *}$ & & \\
SFDI & -0.873 & $-5.879(-6.137)^{* *}$ & $-3.685(-5.014)^{* *}$ \\
& $(-3.742)^{* *}$ & & \\
SGDP & $-2.078(-2.346)^{* *}$ & $21.359(2.239)^{* *}$ & $20.997(1.762)^{*}$ \\
SW & $0.045(0.017)$ & $11.848(1.064)$ & $-16.832(-1.119)$ \\
R ${ }^{2}$ & 0.953 & 0.934 & 0.898 \\
Adjusted R ${ }^{2}$ & 0.942 & 0.913 & 0.873 \\
Log Likelihood & 21.889 & -23.148 & -92.837 \\
Wald test spatial lag & $21.516 \mathrm{p}=0.0001$ & $38.342 \mathrm{p}=0.000$ & $31.57 \mathrm{p}=0.000$ \\
LR test spatial lag & $24.525 \mathrm{p}=0.000$ & $40.984 \mathrm{p}=0.000$ & $34.7 \mathrm{p}=0.000$ \\
Wald test spatial error & $48.317 \mathrm{p}=0.000$ & $100.851 \mathrm{p}=0.000$ & $58.978 \mathrm{p}=0.000$ \\
LR test spatial error & $50.159 \mathrm{p}=0.000$ & $84.073 \mathrm{p}=0.000$ & $58.841 \mathrm{p}=0.000$ \\
\hline
\end{tabular}

Notes: Lag has been chosen based on AIC and SBC.

$\mathrm{t}$ - values are provided in parenthesis.

Asterisks ${ }^{* * *},{ }^{* *}$ and ${ }^{*}$ denote level of significance at $1 \%, 5 \%$ and $10 \%$ respectively.

To enhance the robustness and the reliability of the econometric estimations, both the Wald test and the LR test are employed to examine whether the spatial Durbin model can be simplified to the spatial lag model or the spatial error model. From Table 4, both tests infer that the null hypotheses where the spatial Durbin model can be simplified to the spatial lag and error modes are rejected for all regions. As such, the results confirm that the spatial Durbin model is 
the most appropriate model in estimating the determinants of FDI in all the regions.

\section{Eastern Region}

Based on the estimated results, GDP is negative and statistically insignificant for the Eastern region. Hence, it implies that either the market size is not the determinant of FDI inflow or it is no longer a significant factor as the market is itself already large in the Eastern region. It is apparent that FDI is now indifferent to the market size for the Eastern Region. On the other hand, wage rate is found positive and statistically significant at $5 \%$ significance level. We assumed by proxy and by productivity that labor cost is positively correlated with labor quality. Hence, this result infers that high labor quality is the main determinant of FDI. The result is in line with the findings of Sun et al. (2002), Hong et al. (2008) and Zhang et al. (2010) which revealed that the motive of FDI in the Eastern region was mainly efficiencyseeking. High quality and skilled labors are required to enhance the competitiveness of the MNCs that had invested in this region. Furthermore, Wen (2007) also noted that foreign investors treat the Eastern region as the export platform which is efficiency-seeking in nature. From the initiating policies that started off serious FDI into China and the zoned preferences by planned policy treatments for the coastal areas, the Eastern Region had the longest history in FDI investment and thus tends to be considered as the region that is stable, reliable and more developed infra-structurally. The higher labor cost that had risen is also a phenomenon brought about by the presence of FDI which tends to offer higher wages in the pursuance of higher productivity and output. The significance and the value of 1.341 for the labor cost variable also show that FDI is not deterred by the higher wages but is drawn by the wages itself.

The significance of the spatial variables, namely SFDI and SGDP confirm the presence of spatial interaction effects. The negative coefficient of SFDI suggests that the inflow of FDI to one province is at the expense of other provinces. This suggests that the provinces of the Eastern region are competing rather than complementing each other to attract FDI. The attraction of FDI is not on a concerted basis and it appears that each province is largely on its own in such efforts. Consistent with the outcome on market size, the size of each individual provincial market is seemed to negatively affect FDI inflows. With a negative coefficient of -2.078 , it is apparent that the FDIs entering the 
region are not market-seeking. The positive spatial wages coefficient points out that the MNCs are efficiency-seeking in nature and is very much so. The Eastern region looks to be still in the positon of the export platform for the FDI inflows and remains the backbone of manufacturing FDIs despite the rising wages. The prior history of the FDI policy and development seems to guarantee this position for the Eastern region. Rising wages can always be offset by migrating labor. Unless structural reforms are undertaken on a serious and sustained basis, it appears that the position of the Eastern region vis-à-vis the other two regions as the magnet for FDIs will remain unchallenged for a long time to come.

\section{Central Region}

In contrast with the results of the Eastern region, market size is found to be positive and significant while the coefficient of wage rate is negative and insignificant for the Central region. The results suggest that the FDI inflow to China's inland provinces is market-seeking in nature. Similar results were reported by Wen (2007), Havrylchyk and Poncet (2007), Zhang (2009), Fung and lizaka (2002) and Hong et al. (2008). In addition, the strong positive and significant coefficient of SGDP with the value of 21.359 further signifies the importance of market size of the neighbouring provinces in the region. There seems to be an impact of a joint market size as a whole with probably linked infrastructure of a more contiguous region at closer levels of development. The coastal Eastern region provinces all have individual logistical advantages on their own and need not depend on another province as a conduit for exports. From the policy development perspective, the region is a secondary region in time and priority for FDI attraction as a whole. Only when the coastal regions are overheating that the imbalances between the Eastern and the Central regions were addressed, despite any claims of planned development by regions. From the spatial perspective, FDI inflow to one province responds positively to the expansion of the market size of the neighboring provinces, more so from the perspective of one joint large market for the Central region. On the other hand, the negative and significant coefficient of SFDI implies that the provinces are competing rather than complementing each other in terms of attracting FDI inflow, which is similar to that of the Eastern region. The joint market draw thus does not guarantee joint development in the attraction of FDI. The competitive nature among the provinces is revealed from the high negative coefficient for the spatial FDI variable. This reflects the individualistic provincial 
initiatives in attracting FDI. This seemingly unbridled competition for FDI is reflective of the earlier stage of the development of FDI inflows in earlier periods. The long run situation may however, change as China's domestic firms develop and gain the necessary strength to invest domestically and current policies to build sustainable economies based on domestic demand and internal investments are gearing this region to become more self-contained as the logistics cost of exports from this region is higher without direct access to sea ports. From the results above, the shifts in policy changes currently being pushed should take into account the need for complementary development as a whole among the provinces in the region rather than the apparent unbridled competition revealed. Future studies for FDI must look at the domestic investment in conjunction to be meaningful.

\section{Western Region}

Similar to the Central region, the econometric result shows that GDP is one of the main determinants of FDI as the coefficient is positive and significant. In addition, the positive and significant SGDP further enhances the importance of the expansion of market size in the neighbouring provinces as it provides a positive spill-over effect in terms of attracting FDI inflow. As such, the results infer that the motive of FDI inflow in the Western region is apparently market-seeking in nature. Similar results are seen for the Western and the Eastern regions except that the apparent competition for FDI among the provinces appears to be lower. In addition to that, the coefficient of wage rate appears negative (-2.425) and significant at $10 \%$ significance level. Thus, cheap labor inputs have an obvious attraction to foreign investors. Some previous studies (Liu, 2010; Cheng \& Kwan, 1999; Gao, 2005; Zheng, 2009) found that low labor cost is the key factor to attract FDI inflow to China. Besides, Hong Kong investments are focusing on China's labor-intensive industries and are resource-seeking in nature (Fung et al., 2003) As a result, the results suggest that the motive of FDI in the Western region is a combination of both market-seeking and resource-seeking.

This Western region is located further inland and logistically is at the most disadvantage compared to the two other regions. However, the presence of natural resources allow the region to attract investments into the far west. For a material-resource conscious country as China, the investments moving forward will be more domestic-based than 
foreign-based. With Chinese companies buying mining companies overseas, the development of local mining will be more logically pursued by domestic firms, without having to fear policy changes in other countries that affect resource transfers in the long run. This region's instability may also be a deterrent for FDI inflows. This is reflected by the scale of FDI into this region as compared to the coastal region by a ratio of 1:10.

\section{Conclusion}

This study examined the determinants of FDI inflow in China's three regions using the spatial panel model for the period 1994-2008 and looked at the results from the perspective of initiating policies for FDI into China. From the flows of FDI and the growth of GDP as well as the scale of FDI flows into the three regions, the nature of the FDI inflows are clearly different. The econometric results further revealed the different dynamics of the FDI into the different regions. The uneven distribution of FDI into the three regions of China is a foregone conclusion but such conclusions are linked back not only to the locational advantages but also to the initiating policies of FDI inflows into China. The coastal region is the start-up zone for FDI inflows and has significant locational advantages and also has temporal advantage in view of the years of development before FDI became a serious phenomenon in the Central and Western regions. Because of the locational, temporal and policy advantages, the FDI inflows into the coastal regions are larger in scale, varied and to quality.

Empirically, we have found that the motive of FDI for the Eastern region is mainly efficiency-seeking. The apparent inter province competition for FDI does exist but the level of displacement between the provinces is not high. The entrenched endogenous effects of FDI attracting FDI already exist and this will be a further draw for the coastal region that will outpace the attractiveness of FDI of the region vis-à-vis the other two regions. Since labor quality features strongly as a variable, there is a need to look at maximising the potential of labor from the qualitative point of view. The selective attraction of specific FDI from the qualitative aspect should be the future direction, complemented by service developments to complement the already high quality infrastructure present in the coastal region.

FDI into the Central and Western regions are empirically revealed here as mainly market-seeking. The quantum is lower and the nature of 
FDI is different. The significance and the high value of the coefficient for the spatial market factor reveal attractions arising from a joint market for each of the two regions. However, the significant and high negative coefficients for the spatial FDI variable for both regions show a significant displacement effect by province. The Central region being more contiguous and infra-structurally linked as a region is divided by a seemingly unbridled competition among the provinces for FDI attraction. Being the secondary region in policy terms had saddled the region with a different FDI profile not as lucrative as the export sector. It will not be a disadvantage for China, as a whole, to have a region with a different FDI profile. Current policies to internalize investment from the domestic sources to make provincial economies in the inner regions to become more self contained from domestic demand point of view may yet work out for the Central region as a whole. The endogenous effects of FDI in specific industries are still of much benefit to the region's economy as a whole, as already demonstrated by the coastal regions for the export-based industries, which have given birth to many MNCs from China now seeking to become FDI themselves, exporting Chinese technology and business. Although there are similarities of the nature of the FDI profile between the Central and the Western regions, the scale and nature do vary. With the resource-based nature of investments, the lack of good quality infrastructure, the logistical disadvantages, the Western region may perhaps be targeted for domestic investment, not from the policy of discouragement but more from the encouragement of the domestic companies to invest and procure the resources for internal consumption.

On the overall, the entrepreneurial nature of competition of FDI among the provinces revealed by the spatial FDI factor is a conclusion that cannot be ignored. A more coherent policy on FDI inflows into China is an urgent necessity.

\section{References}

Baltagi, B. H. (2005). Econometric analysis of panel data. West Sussex, England: John Wiley

Boumphrey, S. (2014). China vs. USA: A battle of economic equals? Opinion: GMID.

Boermans, M., Roelfsema, H., \& Zhang,Y. (2009). Regional determinants of FDI in China: A new approach with recent data. Tjalling C. Koopmans Research Institute Dicussion paper series nr: 09-23. 
Buckley, P. J., Wang, C. Q., \& Clegg, J. (2006). The impact of foreign ownership, local ownership and industry characteristics on spillover benefits from foreign direct investment in China. International Business Review, 16, 142-158.

Cheng, L. K., \& Kwan, Y. K. (1999). What are the determinants of the location of foreign direct investment? The Chinese experience, Journal of International Economics, 51, 379-400.

Cheung, K. Y., \& Lin, P. (2004). Spillover effects of FDI on innovation in China: Evidence from the provincial data. China Economic Review, 15, 25-44.

Claro, S. (2009). FDI liberalization as a source of comparative advantage in China. Review of Development Economics, 13, 74-753.

Coughlin, C. C., \& Segev, E. (2000). Foreign direct investment in China: A spatial econometric study. The World Economy, 23, $1-23$.

Dunning, J. H. (2001). The eclectic (OLI) paradigm of international production: Past, present and future. International Journal of the Economics of Business, 8, 173-190.

Elhorst, J. P. (2003). Specification and estimation of spatial panel data models. International Regional Science Review, 26 (3), 244-268.

Elhorst, J. P. (2010). Applied spatial econometrics: Raising the bar. Spatial Economic Analysis, 5, 9-28.

Forbes, K. J. (2005).Capital controls: Mud in wheels of market efficiency. Cato Journal, 25(1), 153-166.

$\mathrm{Fu}, \mathrm{J}$. (2000). Institutions and investments: Foreign direct investment in China during an era of reforms, U.S, University of Michigan Press.

Fung, K. C., \& Iizaka, H. (2002). Determinants of U.S. and Japanese direct investment in China. Journal of Comparative Economics, 30, 567-578.

Fung, K. C., Iizaka, H., \& Siu, A. (2003). Japanese direct investment in China. China Economic Review, 14, 304-315.

Gao, T. (2005). Labor quality and the location of foreign direct investment: Evidence from China. China Economic Review, 16, 274-292.

Girma, S., Gong, Y. D., \& Gorg, H. (2008). What determines innovation activity in Chinese state-owned enterprises? The role of foreign direct investment. World Development, 37, 866-873.

GMID (2015). Risks and vulnerabilities: China. Country briefing.

Hale, G., \& Long, C. (2011). Are there productivity spillovers from foreign direct investment in China? Pacific Economic Review, 16, 135-153.

Havrylchyk, O., \& Poncet, S. (2007). Foreign direct investment in China: Reward of remedy? The World Economy, 30, 1662-1681. 
Ho, C. H. (2004). Determinants of foreign direct investment in China. 16th Annual Conference of the Association for Chinese Economics Studies, Australia (ACESA), Brisbane, QLD, 19-20 July 2004.

Hong, E., Sun, L. X., \& Li, T. (2008). Location of foreign direct investment in China: A spatial dynamic panel data analysis by country of origin. Centre for Financial and Management Studies University of London, Dicussion paper No. 86.

Huang, H., \& Wei, Y. H. D. (2010). Spatial-temporal patterns and determinants of foreign direct investment in China, Erdkunde, 65(1),7-23.

Jiang, C. X., Yang, Q., Li, S. L., \& Wang, Y. (2011). The moderating effect of foreign direct investment intensity on local firms' intangible resources investment and performance implications: A case from China. Journal of International Management, 17, 291302.

Jiang, Q. K., \& Wang, Z. X. (2011). The framework for the introduction of transnational corporations' low-carbon foreign investment in Zhejiang province in China. Energy Procedia 5, 1837-1841.

Kang, H. H., \& Wang, W. H. (2011). The effects of changes in China's business environment on Taiwan's outward foreign direct investment. IPEDR, 13, 29-33.

Kolstad, I., \& Villanger, E. (2007). Determinants of foreign direct investment in services. European Journal of Political Economy. 2(4), 518-533.

LeSage, J. P., \& Pace, R. K. (2009). Introduction to spatial econometrics. Boca Raton, US: CRC Press Taylor \& Francis Group.

Lin, F. J. (2010). The determinants of foreign direct investment in China: The case of 'Taiwanese firms in the IT industry". Journal of Business Research, 63, 479-485.

Liu, W. H. (2010). Determinants of FDI inflows to China: An empirical analysis of source country characteristics. Taipei International Conference On Growth, 1-18.

Liu, L. G., Chow, K., \& Li, U. (2007). Has China crowded out foreign direct investment from its developing East Asian neighbors? China \& World Economy, 15, 70-88.

Lv, L. C., Wen, S. M., \& Xiong, Q. Q. (2010). Determinants and performance index of foreign direct investment in China's agriculture". China Agricultural Economic Review, 2, 36-48.

McKenney, K. H. (1993). An assessment of China's special economic zones. Washington, D.C., Fort McNair.

Pan, Y. G. (2003). The inflow of foreign direct investment to China: The impact of country-specific factors. Journal of Business Research, 56,829-833. 
Sun, Q., Tong, W., \& Yu, Q. (2002). Determinants of foreign direct investment across China. Journal of International Money and Finance, 21, 79-113.

Tahir, R. \& Larimo, J. (2005). Understanding the strategic motivations of finish manufacturing FDIs in emerging Asian economies. Asian Business and Management, 4, 293 - 313.

Wadhwa, K., \& Reddy, S. (2011). Foreign direct investment into developing Asian countries: The role of market-seeking, resource-seeking and efficiency-seeking factors. International Journal of Business and Management, 16, 219-226.

Wei, Y. Q., Liu, X.M., \& Wang, C.G. (2001). Causal links between foreign direct investment and trade in China. China Economic Review, 12, 190-202.

Wen, M. (2007). Foreign direct investment, regional market conditions and regional development: A panel study on China. Economics of Transition, 15, 125-151.

Zhang, K. H. (2001). How does foreign direct investment affect economic growth in China? Economics of Transition, 9, 679-693.

Zhang, Y. (2009). A different look at inward FDI into Mainland China. United Nations University-MERIT, Working Papers, No. 60.

Zhang, Y., Li, H.Y., Li, Y., \& Zhou L. A. (2010). FDI spillovers in an emerging market: The role of foreign firms' country origin diversity and domestic firms' absorptive capacity.Strategic Management Journal, 31, 969-989.

Zhao, Z. X., \& Zhang, R. L. (2010). FDI and industrial productivity in China: Evidence from panel data in 2001-06. Review of Development Economics, 149(3), 656-665.

Zheng, P. (2009). A comparison of FDI determinants in China and India". Thun-derbird International Business Review, 51(3), 263-279. 